active and placebo preparations should be indistinguishable (short of chemical analysis) by any patient, nurse, or physician of average intelligence and curiosity. Yet in most reports this potentially crucial aspect of the experimen is dismissed in a few words such as, "identica placebo capsules were used." It is only by chance that we recently learnt of a number of trials in which, although the capsules were indeed identical, the difference in the contents was childishly obvious. This is a particularly hazardous situation where (as is often the case) the active substance has a characteristic flavour or texture and is either well known or is easily available to the inquisitive participant as a basis of comparison.

May we suggest that journals make it a matter of editorial policy that authors wishing to use the term "double-blind" be required to justify their use of the term by specifying the steps taken to ensure that the preparations used were truly indistinguishable? A simple yet effective test is to offer the active and placebo preparations (together with the conventional presentation of the drug as a standard of reference) to a "taste committee" of 20 or 30 colleagues and to challenge them to identify the placebo preparation by any of the five senses. Unless a published report includes evidence that some such procedure has been carried out, the results should be accepted with a measure of healthy scepticism.

$\mathrm{T} \mathrm{W}$ ANDERSON

M J ASHLEY

E A Clarke

Department of Preventive Medicine and Biostatistics,

Faculty of Medicine, University of Toronto,

\section{Plasticity in the nervous system}

SIR,-Your interesting leading article on this subject (24 January, p 182) raises a number of interesting points while managing at the same time to give the most superficial survey available. To suggest that evidence in support of plasticity in the central nervous system (CNS) has mostly come to light in the last six years is to ignore, for example, the prodigious amount of evidence summarised by Windle. ${ }^{1}$ There is no mention of Russian workers² who claim complete functional recovery after CNS lesions. This work obviously must be met with considerable scepticism, but it was of sufficient interest for the USA to send a skilled and experienced official observer to report on it while Britain continued to ignore any work which could conceivably have any clinical implication. The Russian experiments are now being repeated in the USA.

Sprouting in the CNS following a partia lesion was first demonstrated nearly 20 years ago, ${ }^{3}$ and plastic changes were described as a possible explanation for spinal shock in 1963. It was suggested (more than six years ago) that following partial denervation the intact CNS will react in such a way as to neutralise the change in condition and that this will be seen in terms of a reorganisation at the synaptic zone resulting in previously unused or little-used pathways becoming more effective. This suggestion has been confirmed in that cells deprived of their major input respond to new stimuli' and previously "silent" pathways become easily elicited.' Repetitive stimulation may produce a structural change in appropriate synapses. ${ }^{8}$ Glial changes (not mentioned in your article) are intimately linked with changes of reorganisation or regeneration. ${ }^{9}$ In the USA there are centres (such as Rancho Los Amigos in California, the Texas Institute for Rehabilitation and Research, and Downstate University, New York) which are actively engaged in clinical applications of repetitive stimulation in the problems of rehabilitating patients with chronic neurological deficit.

In Britain there appears to be a considerable rift between full-time research workers and those who attempt the different task of combining clinical work with research into "basic" mechanisms. The latter are usually regarded as amateurs who are more trouble than they are worth. I know, for example, of at least two holders of neuroscience chairs who will do their utmost to prevent any clinical neurologist from attempting continuing research, and one of these, in his zeal, will attempt to prevent publication and the granting of research money. Yet in neurology, when one thinks of major work in, say, the fields of muscle, nerve, and demyelination it is people like Walton, Thomas, Gilliat and Macdonald, etc, who have made the major contributions as active clinical neurologists before attaining their present academic respectability.

In the USA there appears to be a quite different climate and a much closer link between academic and clinical workers. Perhaps this is due to the formation of the National Paraplegia Foundation, which exists to promote and encourage co-operative work in the field of regeneration. It seems to me, Sir, that we should have such an organisation in this country. Clinical neurologists and specialists in rehabilitation, for example, badly need the advice and direction of research workers such as Raisman and Blakemore and I venture to suggest that the opposite may be of some benefit.

\section{S ILLIS}

Wessex Neurological Centre, Southampton General Hospital, Southampton

Windle, W F, Regeneration in the Central Nervous System. Springfield, Thomas, 195

Natinian, L A and Andreasian, A S, Enzyme Therapy in Organic Lesions of the Spinal Cord (in Russian; English summary). Yerevan, Academy of Science

${ }^{3}$ Liu, C N, and Chambers, W W, Archives of Neurology and Psychiatry, 1958, 79, 46.

Illis, L S, Experimental Neurology, 1963, 8, 328.

D Williams. London, Butterworths, 1967.

Wall, P D, and Egger, M D, Nature, 1971, 232, 542. Merrill, E G, and Wall, P D, fournal of Physiology, 1972, 226, 825 .

Illis, L S, Nature, 1969, 223, 76.
Illis, L S, Brain, 1973, 96, 61.

\section{A place to be born}

SIR,-The members of the Study Group on Home Confinement of the National Childbirth Trust (31 January, p 279) have confused the important question of maternal satisfaction by using an erroneous analogy. They present the Swedish and Dutch examples, arguing that since both countries have a low perinatal mortality rate and Sweden has $100^{\circ}$ deliveries in hospital while Holland has only $50 \%$, then "it is not the place of confinement but rather the quality of life and care that is the critical point at issue." They seem to forget that the important difference between these countries lies in the time it takes to get a patient to hospital; Sweden has 47 persons per square mile, whereas Holland has 840 persons per square mile. One of the group was present (with $M R$ ) at a recent study day when Pro- fessor Kloosterman of Amsterdam informed them that any patient treated in domiciliary practice in Holland could be transferred to a hospital midwifery unit within 20 minutes of calling the ambulance. We also have a concentrated population in the UK, but because of our congested roads there must be very few places from which the mother could be in hospital within many multiples of that period.

The group are on stronger ground when they point out that it is "the quality of life" that matters in preventing perinatal mortality. It is well known that perinatal mortality is closely related to social class (that is, inheritance, education, and wealth). Both Holland and Sweden on average have a healthier population than that of the UK, with consequently lesser hazards to the mother and baby in labour whether delivered at home or hospital.

However, something can be done now about meeting the main objection of the group to hospital delivery. Why should human and emotional factors have to suffer in a hospital environment? It would be more profitable (and cost practically nothing) if the group put their efforts and energies into practising a policy designed to satisfy the mother in hospital, as midwives, obstetricians, paediatricians, and anaesthetists try to do in both the large obstetric units in Cardiff.

These measures include: (1) Teach all who are in contact with the mother that having a baby must be made a happy occasion and is in no way to be equated with having a surgical operation. (2) Explain as much as possible to the mother about what is going to happen (only $50^{\circ}$ of mothers in Cardiff come to mothercraft classes so that the remainder must be approached in the antenatal clinic, or even after admission). (3) Make the father (or any companion) welcome at all times in the delivery suite and the ward. Someone (preferably a personal midwife) should be with the mother in labour at all times. (4) Allow the mother to choose the method of pain relief, or none at all, after explanation and without pressure, provided only that the method is safe for her and her baby. (5) Let the mother look after her baby herself. (6) Periodically assess whether these measures are being carried out.

In this way it is possible to combine "physical safety ... in terms of mortality and morbidity" with "human and emotional factors." When these changes are instituted and assessed the group may be able to see more clearly whether any case for home delivery still exists.

$\begin{array}{ll}\text { MichaEl Rosen } & \text { J ANDREWS } \\ \text { GARETH ReES } & \text { BRYAN HIBBARD } \\ \text { W P JAMES } & \text { JAMES F PEARSON } \\ \text { M E G LAWRENCE } & \text { JUDITH B WEAVER } \\ \text { SYBIL F PRICE } & \text { GFRAINT L W WLLIAMS }\end{array}$

Departments of Anaesthetics and Obstetrics,

St David's Hospital and University Hospital of Wales,
Cardiff

\section{Immunisation against whooping cough}

SIR,-The recommendation of the Joint Committee on Vaccination and Immunisation to continue the routine use of whooping-cough vaccines (20 September, p 687) was based on three considerations: (1) whooping cough is still a severe disease, particularly in infants; (2) current vaccines offer a high degree of protection against the disease; and (3) the hazard of the disease exceeds the hazards associated with immunisation. 
A report on the severity of the disease has now been published by Dr Christine L Miller and $\mathrm{Mr}$ W B Fletcher (17 January, p 117). An expert analysis of the effectiveness of whooping-cough vaccines has been made by Professor G T Stewart (31 January, p 283). There is no report on the hazards associated with immunisation and the joint committee has made it clear that this information will not be speedily provided. Since parents will not be influenced by any statistics about the disease or the effectiveness of the vaccines until they have precise information about vaccine risks, we suggest that any debate on the continuation of whooping-cough vaccine should regard this as the major issue.

Two years ago we started to collect details from parents of serious reactions suffered by their children to immunisations of all kinds. In $65^{\circ}{ }^{\prime}$ of the cases referred to us reactions followed "triple" vaccination. The children in this group total 182 to date; all are severely brain-damaged, some are also paralysed, and five have died during the past 18 months. Approximately $60^{\prime \prime}$ " of reactions (major convulsions, intense screaming, collanse, etc) occurred within 24 hours of vaccination, $80^{\prime \prime}$ ' within three days, and all within 12 days. During the period 1969-74, when 64 deaths resulted from whooping cough, 56 cases of severe brain damage followed vaccination.

These cases have been referred to the DHSS over the past two years. As the figures steadily increased and we discovered that there were doubts about the safety of whoopingcough vaccines we asked the DHSS if current vaccines could be withdrawn until safer vaccines were available. When the recommendation to continue the use of current whooping-cough vaccines was published we asked the DHSS if there were any plans to study our cases. The Department insists, however, that the incidence of severe reactions to whooning-cough vaccines is low and states that there are no plans to study our cases at present.

Health specialists are concerned about the fall in acceptance rates for all immunisations. Paradoxically, perhaps, the statement from the joint committee about whooping-cough vaccination was jssued because of a similar concern. It is parents, however, who make or break accentance rates and thcy are not convinced that the hazards associated with whooping-cough immunisation are low or that this is a subject which can be shelved while lengthy studies are carried out and available material is ignored.

ROSEMARY Fox Secretary Shipton-on-Stour Association of Parents of Warwicks

\section{Transcendental meditation}

SIR,-I feel that your expert has answered the question about transcendental meditation (TM) (10 January, p 88) in what appears to be an uninformed and superficial way as if he has not really studied the subject. It must first be stated that TM has nothing to do with "religious beliefs" and that it has nothing to do with mysticism. I also feel that the reference to "European culture" and "such religions" (by implication TM) is just not to the point. On the other hand it is fair to say that TM has its origin in Indian culture and, having said already that it is not a religion, surely
Christianity, which is a religion, has its roots also in another culture, so why reject TM on such grounds? Again, in the last sentence but one your expert speaks about "a need for such religious experience" when every teacher of TM points out that it has nothing to do with it.

Let me therefore try to define what $T M$ is and what its value might be. (1) TM is a technique to achieve relaxation and its experiential aim is to transcend thinking-in other words, to achieve a state of non-thinking ("thoughtlessness"). (2) The value of TM is not only, as mentioned above, relaxation, but a state of peace of mind which permits the practitioner to respond much more purposefully to stress, accept himself and his foibles and those of his fellow men more readily and permits a more purposeful response in a nonaggressive adaptive manner. From the advanced meditators I know it would also seem to induce a state of serene joyfulness. I do not know whether your expert is aware of the considerable amount of scientific data that have been collected by this movement. I recently attended a medical meeting on the subject when, indeed, very convincing research experiments were produced. from the departments of physiology and psychology of the universities of Exeter and Bristol, but of course the main body of experimental data has been collected from the United States. One series of data which was especially beyond reasonable doubt showed that once in a community a saturation rate of $1 \%$ of meditators was achieved the crime rate went down by $17^{\circ} \%$ Surely such a promising technique should not be rejected lightly. I also believe that it is a valid method of primary prevention of psychiatric disorder within a certain spectrum of psychopathology. I have included the subject among the techniques of primary prevention of psychiatric disorder in a key paper which I will read to the Joint World Psychiatric Association/South Pacific Commission Conference on Primary Prevention of Psychiatric Disorder to be held in Tahiti in March 1976.

Yeovil District Hospital,

K E SCHMIDT

Yeovil, Somerset

\section{Ethics of the placebo}

SIR,-In their paper "Do placebos alter sleep ?" (24 January, p 195) Miss Kirstine Adam and her colleagues report that they deliberately misled volunteers about the nature of a placebo pill. I contend that it is unethical to lie to volunteers.

Liphook, Hants

MARY RICE

**We showed this letter to Miss Adam and her colleagues, whose reply is printed bleow. -ED, BMF

SIR, - The medical profession has, throughout history, relied heavily upon placebo effects and therefore on a degree of deception. It still does. Must it be wrong to investigate placebos? We think it is not.

Our volunteers were actually in a larger study, during which they would later be taking nitrazepam. They had given consent to a sleeping pill, which may make our deception less heinous, though it does not negate it. Our pill, being inert, did no positive harm- certainly less than many genuine sleeping pills can do.

There is no unanimity about whether deception is always wrong-is the surgeon who misleads his patient and says she has not got cancer always wrong? We believe that the general body of thoughtful people would not regard our research as improper, but we are willing to respect the views of those who think differently.

KiRstine ADAM IAN OSWALD

University Department of Psychiatry,

University Department of Psy
Royal Edinburgh Hospital,
Edinburgh

\section{Effect of beta-blockade in chronic renal failure}

SIR,-In 1974 deterioration in renal function after $\beta$-adrenergic blockade in three patients with chronic renal failure, one of whom recovered renal function after withdrawal of therapy, was reported from this unit. ${ }^{1}$ This provoked some controversy and we wish to report two further cases.

Case 1-A 34-year-old woman had been treated with debrisoquine for seven years for hypertension secondary to chronic pyelonephritis. The control of blood pressure had been poor because of sporadic self-medication with phenothiazines, frusemide, and tryptizol. Renal function had been stable with a plasma urea of 6-7 mmol/1 (36-42 mg/ $100 \mathrm{ml})$, creatinine $200-205 \mu \mathrm{mol} / 1(2 \cdot 26-2 \cdot 32 \mathrm{mg} /$ $100 \mathrm{ml}$ ) and an endogenous creatinine clearance of $30 \mathrm{ml} / \mathrm{min}$. Propranolol $40 \mathrm{mg}$ three times daily was started. After six days the plasma urea and creatinine rose to $15.5 \mathrm{mmol} / 1(93 \mathrm{mg} / 100 \mathrm{ml})$ and $270 \mu \mathrm{mol} / 1(3.05 \mathrm{mg} / 100 \mathrm{ml})$ respectively and the blood pressure was unchanged at $140 / 100 \mathrm{~mm} \mathrm{Hg}$. The drug was discontinued; the plasma urea reached a maximum of $22 \mathrm{mmol} / 1(132 \mathrm{mg} / 100 \mathrm{ml})$ and then began to fall, but it was nearly a month before renal function returned to control values.

Case 2-A 28-year-old man with chronic renal failure secondary to chronic pyelonephritis had been treated for hypertension with debrisoquine. Outpatient blood pressure recordings varied between $170 / 125$ and $150 / 110 \mathrm{~mm} \mathrm{Hg}$. Renal function had been stable for over six months with a plasma urea of $18-20 \mathrm{mmol} / 1(108-120 \mathrm{mg} / 100 \mathrm{ml})$ and plasma creatinine of $440-450 \mu \mathrm{mol} 1$ (4.97$5.09 \mathrm{mg} 100 \mathrm{ml}$ ). Propranolol $40 \mathrm{mg}$ three times daily was started. After six weeks the blood pressure had fallen to $110 / 80 \mathrm{~mm} \mathrm{Hg}$ and he developed pulmonary oedema. The plasma urea had risen to $31.6 \mathrm{mmol} / 1(190 \mathrm{mg} / 100 \mathrm{ml})$ and despite stopping the $\beta$-blocker renal function did not recover and he is now on intermittent haemodialysis.

The sudden deterioration in renal function in these patients was related to administration of the $\beta$-blocker drug as there was no oligaemia, infection, or other change in drug therapy, one patient recovered when the drug was withdrawn, and renal function had been stable for the previous six months. The deterioration was possibly due to reduced renal perfusion following a reduction in cardiac output, accompanied in case 2 by a fall in blood pressure. This further experience confirms our previous suggestion that $\beta$ adrenergic-blocking drugs may cause a permanent reduction in renal function in patients with chronic renal failure and should be used only when frequent supervision of renal function is possible.

C P SWAINSON R J WINNEY

Medical Renal Unit,

Royal Infirmary,

Fdinburgh

Warren, D J, Swainson, C P, and Wright, N, British 